\title{
Rhizosphere management by biochar and leaching improved plant performance in fresh bauxite residue sand
}

Mehran Rezaei Rashti a, Maryam Esfandbod ${ }^{\mathrm{a}^{*}}$, Ian R. Phillips ${ }^{\mathrm{b}}$, Chengrong Chen ${ }^{\mathrm{a}^{*}}$

${ }^{a}$ Australian Rivers Institute, School of Environment and Science, Griffith University, Nathan, Qld 4111, Australia

b Department of Agriculture and Fisheries, Agri-Science Queensland, Toowoomba, Qld 4350, Australia

*Corresponding authors email address: c.chen@griffith.edu.au; m.esfandbod@griffith.edu.au 


\section{Abstract}

High sodicity and Low nutrient retention in bauxite-processing residue sand (BRS) disposal areas restrict sustainable vegetation management in this highly alkaline environment. Although previous investigations have reported the beneficial effect of organic amendments on BRS rehabilitation, little is known about the underlying mechanisms of this complicated process, particularly after supplementary leaching of biochar amended BRS. We have investigated the coupled effect of supplementary leaching process, biochar [aged acidic (AC) vs alkaline pine (PC)] amendment and di-ammonium phosphate (DAP) fertilisation on rhizosphere nutrient dynamic and ryegrass performance in a 116-day glasshouse study. Biochar amendment in DAP+PC and DAP $+\mathrm{AC}$ treatments significantly increased and decreased $\mathrm{pH}$ (0.3 - 0.5 units) in all BRS rhizosphere and rootfree zones, respectively. The application of alkaline and acidic biochars to BRS have reduced ammonia volatilisation $(25-80 \%)$ and increased nitrogen retention $(9-72 \%)$ in comparison with DAP treatment. Supplementary leaching had no significant effect on BRS rhizosphere pH, but reduced the EC values by ca. $62 \%$ in biochar-amended treatments. The leachates' $\mathrm{pH}$ remained unchanged (ca. 8) throughout the experiment, while their EC reduced in AC (6 folds) and PC (9 folds) amended treatments, with lower reduction in rhizosphere than root-free zones. The interaction of applied biochars and plant roots generally decreased nutrient leaching from rhizosphere in comparison with root-free zones. Sodium was the dominant cation in the leachate of all treatments and cumulative abundance of exchangeable cations were in the order of $\mathrm{Na}^{+}>\mathrm{Ca}^{2+}>\mathrm{K}^{+}>\mathrm{Mg}^{2+}>$ $\mathrm{Al}^{3+}$. The reduction of BRS salinity has increased plant biomass (ca. 47\%) in biochar amended treatments by improving the capacity of fresh BRS rhizosphere for plant establishment.

\section{Keywords:}

Bauxite-processing residue sand, salinity, alkalinity, biochar, leaching, revegetation 


\section{Introduction}

The increasing demand followed by fast development of alumina industry (from $177 \mathrm{Mt}$ in 2005 to $270 \mathrm{Mt}$ in 2016) in recent years, has caused a significant challenge for sustainable remediation of its by-products (Xu et al., 2018). The extraction of alumina from bauxite ore, using sodium hydroxide under high temperature and pressure (Bayer process), yields nearly two tonnes of highly alkaline (pH 11-13), saline and dispersive bauxite-processing residue waste per tonne of produced alumina, which has very low nutrient retention capacity and microbial activity. This residue is usually deposited in close distance from alumina refineries. Alcoa of Australia (Alcoa) separates bauxite-processing residue into the fine (red mud, $<150 \mu \mathrm{m}$ ) and coarse (residue sand, $>150 \mu \mathrm{m}$ ) fractions before transportation to the storage areas. Bauxite-processing residue sand (BRS) is used to construct the outer embankments of the storage areas, which encompass the produced red mud. Progressive rehabilitation of the residue sand embankments, through development of a soil-like medium to support sustainable vegetation cover, considered as one of the main parts of closure process in residue storage areas (Zhu et al., 2018). This strategy would increase physical stability of storage areas, suppress dust emission and reduce the risks associated with discharge of alkaline drainage to surrounding environment.

Sustainability of vegetated native plant species (tolerant to high salinity and sodisity) mainly depend on water and nutrient dynamics in BRS harsh environment (Goloran et al., 2014; Gwenzi et al., 2011). Incorporation of organic amendments such as biosolid, manure, compost, plant materials and biochar to BRS has been found to improve BRS properties by increasing its aggregate stability (Jones et al., 2011; Zhu et al., 2016), cation exchange capacity, nutrient availability (Goloran et al., 2015; Thiyagarajan et al., 2011), water holding capacity (Courtney et al., 2009; Munshower, 1994; Zhu et al., 2017) and microbial activity (Jones et al., 2010). These physicochemical improvements are likely to help the ecological rehabilitation of BRS disposal areas (Jones et al., 2011). Water leaching process is also recommended as a promising strategy to ameliorate the high salinity and 
alkalinity of bauxite-processing residue (Zhang et al., 2011) and high sodium $\left(\mathrm{Na}^{+}\right)$concentration has been reported in bauxite-processing residue leachate (Xiang-feng Kong et al., 2018). Taking full advantage of the available water resources, such as local rainfall and recovery of produced leachate for alumina extraction process, would further justify the practical implication of leaching process in BRS disposal areas. However, little is known about the effect of organic amendments' incorporation to BRS on its leachate's chemical composition and potential environmental impacts.

The presence of plants in any restoration system also has a significant effect on the chemistry and biology of the surrounding environment. Plants' roots and their rhizosphere exudates facilitate aggregation of BRS particles, which consequently improve local microbial biomass and activity. Process based understanding of the interaction between organic amendments and plant roots, in rhizosphere area, is critical for the adoption of sustainable management strategies in the BRS storage areas. Therefore, the main objectives of the present study were to: (1) investigate the effect of biochar amendments on unweathered BRS's nutrient loss, leachate chemical composition and rehabilitation performance; and (2) assess the coupled effects of biochar application and supplementary leaching process on sustainable plant establishment in highly alkaline BRS. The underlying hypothesis was that biochar amendment to BRS would decrease nutrient losses through leaching process and consequently increase plants biomass and nutrient uptake.

\section{Materials and Methods}

\subsection{Bauxite-processing residue sand and biochars physicochemical properties}

The unweathered and untreated (fresh) BRS was collected from Alcoa of Australia (Alcoa) Kwinana Residue Storage Area ( $\left.32^{\circ} 11^{\prime} \mathrm{S}, 115^{\circ} 49^{\prime} \mathrm{E}\right)$, Western Australia. The BRS was air dried and sieved $(<2 \mathrm{~mm})$ prior to the experiment. It has contained $98 \%$ sand, $1 \%$ silt and $1 \%$ clay with initial $\mathrm{pH}$ of 
11.3 (1:5 water), EC of $34 \mathrm{ds} \mathrm{cm}^{-1}$, and water holding capacity (WHC) of $254 \mathrm{~g} \mathrm{~kg}^{-1}$. The sieved BRS was amended with gypsum at $1 \%$ (w/w basis), rewetted to $60 \%$ WHC and incubated for two weeks (Alcoa's rehabilitation prescription). After incubation, the gypsum amended BRS was leached with distilled water equivalent to average annual rainfall of the Kwinana area (i.e.758 mm; five leaching events). Preliminary experiments have shown that this process is necessary for the preparation of bauxite-processing residue sand and without leaching, the fresh BRS is unlikely to support plant growth and vegetation establishment. Two biochars with contrasting physiochemical characteristics, namely acidic aged eucalyptus biochar (AC) and Alkaline pine biochar (PC), were used in this experiment. The AC biochar was produced during the wild fire in 1969 at Peachester State Forest $\left(26^{\circ} 50^{\prime} \mathrm{S}, 152^{\circ} 53^{\prime} \mathrm{E}\right)$ Sunshine Coast hinterland of Queensland, Australia, with pH of 3.1 (1:5 water). The PC biochar was produced at $700{ }^{\circ} \mathrm{C}$ in a well-controlled furnace, under oxygen free condition, with final resident time of 1 hour and $\mathrm{pH}$ of 8.6 (1:5 water). Detailed properties of the BRS and applied biochars are reported in Table A.1.

\subsection{Pot trial design}

The cylindrical polyethylene pot designed for this experiment $(12 \mathrm{~cm}$ diameter and $12.5 \mathrm{~cm}$ height $)$ was comprised of three concentric compartments namely: rhizosphere $(0-3 \mathrm{~cm}$ radius form centre), root-free zone 1 (3-4 cm radius form centre) and root-free zone 2 (4-6 cm radius form centre). The compartments were separated (but not isolated) using weaved stainless still frames covered with 40$\mu \mathrm{m}$ polyethylene mesh (Fig. A.1). Detachable transparent polyethylene gas chambers were also designed for $\mathrm{NH}_{3}$ volatilisation measurement. The pots had separate leachate collection tubes installed in rhizosphere and root-free zones (combined leachate from root-free zone 1 and root-free zone 2) and gas chambers could be connected to the pot using an elastic rubber band and high vacuum silicon grease to provide an airtight condition during gas sampling events. The rhizosphere 
in this study is defined as the area that is in close contact with growing plants' roots and their exudates. The root-free zone 1 is defined as the area that is not in contact with growing plants' roots but affected by their exudates, while the root-free zone 2 is defined as the area that is not affected by growing plants' roots and their exudates.

The study was conducted with four main treatments in six replicates namely: (1) Control (CK): BRS (1580 g pot $\left.^{-1}\right)$ without adding $\mathrm{N}$ fertiliser and biochar; (2) DAP: BRS (1580 g pot $\left.^{-1}\right)+177.2 \mathrm{mg} \mathrm{N}$ pot $^{-1}$, equivalent to $574.2 \mathrm{~kg} \mathrm{~N} \mathrm{ha}^{-1}$ as Di-ammonium phosphate; (3) DAP + AC: BRS (1580 $\left.\mathrm{g} \mathrm{pot}^{-1}\right)$ + Di-ammonium phosphate $+\mathrm{AC}$ (the same $\mathrm{N}$ rate of DAP plus $26.33 \mathrm{~g} \mathrm{pot}^{-1}$, equivalent to 85.0 ton $\mathrm{ha}^{-1} \mathrm{AC}$ in the top $\left.30 \mathrm{~cm}\right)$; and (4) DAP + PC: BRS $\left(1580 \mathrm{~g} \mathrm{pot}^{-1}\right)+$ Di-ammonium phosphate + PC (the same $\mathrm{N}$ rate of DAP plus $13.17 \mathrm{~g} \mathrm{pot}^{-1}$, equivalent to 42.5 ton $^{-1} \mathrm{PC}$ in the top $30 \mathrm{~cm}$ ). The $\mathrm{AC}$ and PC biochars (passed through $2 \mathrm{~mm}$ sieve) were added to BRS at a ratio of 1:20 (i.e. 5\% on a v/v basis) and mixed thoroughly by end-over-end shaking for 24 hours to make a uniform mixture.

The moisture content of each treatment then adjusted to $25 \% \mathrm{WHC}$ (WHC $=25.4 \%$ moisture for BRS, 29.1\% moisture for BRS + AC and 30.3\% moisture for BRS + PC), using distilled water and Hoagland solution (120.4 ml per pot containing $235 \mathrm{mg} \mathrm{L}^{-1} \mathrm{~K}, 200 \mathrm{mg} \mathrm{L}^{-1} \mathrm{Ca}, 31 \mathrm{mg} \mathrm{L}^{-1} \mathrm{P}, 64 \mathrm{mg} \mathrm{L}^{-1}$ $\mathrm{S}, 48 \mathrm{mg} \mathrm{L}{ }^{-1} \mathrm{Mg}, 0.5 \mathrm{mg} \mathrm{L}^{-1} \mathrm{~B}, 5 \mathrm{mg} \mathrm{L}{ }^{-1} \mathrm{Fe}, 0.5 \mathrm{mg} \mathrm{L}^{-1} \mathrm{Mn}, 0.05 \mathrm{mg} \mathrm{L}^{-1} \mathrm{Zn}, 0.02 \mathrm{mg} \mathrm{L}^{-1} \mathrm{Cu}$ and 0.01 $\mathrm{mg} \mathrm{L}^{-1} \mathrm{Mo}$, without $\mathrm{N}$ source); the latter to provide essential nutrients for plant growth. Considering that biochar amendment has changed the WHC of fresh BRS, different treatments would have slightly different moisture content $(25 \%$ - 30\% moisture) while the percentage of WHC remain the same in all treatments. Treated samples were pre-incubated for one week at $25{ }^{\circ} \mathrm{C}$, after which the moisture of treatments were re-adjusted to $50 \%$ WHC with distilled water and Di-ammonium phosphate (DAP) solution for control and fertilised treatments, respectively. The prepared samples then transferred to pots $(50 \% \mathrm{~W} / \mathrm{W}$ in rhizosphere, $17 \% \mathrm{~W} / \mathrm{W}$ in root-free zone 1 and $33 \% \mathrm{~W} / \mathrm{W}$ in root-free zone 2) and 30 Wimmera rigid ryegrass (Lolium rigidum) seeds were sown in the rhizosphere compartment of each pot. Following germination of ryegrass seed, 20 plants were left in 
each pot. The pots were maintained at 50\% WHC (by adding distilled water every three days) and 22 $\pm 2{ }^{\circ} \mathrm{C}$ for the first eleven weeks of the experiment to help the establishment of ryegrass plants prior to inducing supplementary leaching (Fig. A.2). At the end of this period, three replicates of each treatment went through additional five leaching events with one week intervals $(190 \mathrm{~mm}$ per pot in each event, equal to average three months rainfall in the Kwinana Refinery, Western Australia) using distilled water (defined as "leached") and the other three replicates remained unchanged (defined as "unleached"). This process finally resulted in an experiment with eight treatments in three replicates. The pot trial was continued for five weeks and terminated after 116 days. The plants' above- and below-ground biomass were harvested at the end of experiment.

\subsection{Bauxite-processing residue sand, leachate and plant analysis}

The $\mathrm{NH}_{3}$ volatilisation was measured using the sponge trap method modified by Chen et al., (2010). Ammonia trapping solution was a 1:3 ratio mixture of glycerol and concentrated sulfuric acid. In the first two weeks of the experiment, samples were collected after incubation periods of 1, 4, 7 and 14 days, respectively. After this initial two weeks, the sponges were incubated for 16 hours on the $2^{\text {nd }}$ and $5^{\text {th }}$ days of each weak to monitor $\mathrm{NH}_{3}$ volatilisation for the remainder of the experiment. The captured ammonia was extracted with $2 \mathrm{M} \mathrm{KCl}$ (1:10 ratio) using an end-over-end shaker for 1 hour and filtering through Whatman 42 filter paper. The $\mathrm{NH}_{4}{ }^{+}-\mathrm{N}$ concentration in the supernatant was determined by SmartChem ${ }^{\circledR 200}$ Discrete Chemistry Analyser (WESTCO Scientific Instruments Inc.).

The plants' above- and below-ground biomass were measured for each treatment by the end of experiment. The root lengths were estimated by a modified line intersect method (Tennant, 1975). Total C (TC) and N (TN) contents of plants and BRS treatments were measured by dry combustion using a LECO CN analyser (TruMac NO. 830-300-400). The $\mathrm{pH}$ and EC values in BRS treatments 
(1:5 distilled water) and leachate samples were measured using a glass electrode (Rayment and Lyons, 2011). The mineral $\mathrm{N}\left(\mathrm{NO}_{3}{ }^{-} \mathrm{N}\right.$ and $\left.\mathrm{NH}_{4}{ }^{+}-\mathrm{N}\right)$ concentration in $\mathrm{BRS}$ treatments and leachate ( $\mathrm{pH}$ of leachate was reduced to 3 by adding concentrated hydrochloric acid $(\mathrm{HCl})$ prior to chemical analysis) samples were determined by SmartChem ${ }^{\circledR 2} 200$ Discrete Chemistry Analyser (WESTCO Scientific Instruments Inc.). The concentration of major bioavailable nutrients ( $\mathrm{P}, \mathrm{K}, \mathrm{Ca}, \mathrm{Mg}, \mathrm{Na}$ and $\mathrm{Al})$ in the leachate samples were measured using an inductively coupled plasma optical emission spectrometer (ICP-OES; Perkin Elmer; Optima 8300). Microbial biomass C (MBC) and N (MBN) of treatments were determined using the chloroform fumigation-extraction method (Vance et al., 1987) by applying an EC factor of 2.64 and an EN factor of 2.22. The concentration of samples' dissolved organic $\mathrm{C}(\mathrm{DOC})$ and $\mathrm{N}(\mathrm{DON})$, as well as their inorganic $\mathrm{C}$ (IC) contents were measured using a

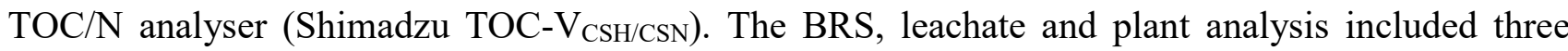
replicates from each treatment and the results were expressed on an oven-dry basis.

\subsection{Data processing and statistical analysis}

Statistical analysis was performed by analysis of variance using the IBM SPSS Statistics 23 software package (IBM Corp. Released 2013. IBM SPSS Statistics for Windos, Version 23.0. Ar-monk, NY: IBM Corp.). The differences at $\mathrm{P} \leq 0.05$ between experimental treatments using LSD test considered statistically significant and all variables were tested for normality of distribution using KolmogrovSmirnov test. 


\section{Results and discussion}

\section{1. $\mathrm{pH}$ and EC of bauxite-processing residue sand and leachate solution}

$\mathrm{pH}$ is one of the main regulating factors of $\mathrm{N}$ loss in highly alkaline environments such as BRS disposal areas (Chen et al., 2010). Successful revegetation of residue disposal areas is highly dependent on reducing residual alkalinity (Liao et al., 2018), as high $\mathrm{pH}$ in the rhizosphere reduce solubility and availability of nutrients for plant uptake (Gahoonia, 1993; Hedley et al., 1982). Comparing different treatments under leached and unleached conditions indicated that biochar application in $\mathrm{DAP}+\mathrm{PC}$ and $\mathrm{DAP}+\mathrm{AC}$ treatments significantly $(\mathrm{P}<0.05)$ increased and decreased $\mathrm{pH}$ in all BRS layers, respectively (Table 1). Although leaching showed to have no significant effect on $\mathrm{pH}$ at rhizosphere and root-free zone 1 , but reduced $(\mathrm{P}<0.05)$ the $\mathrm{pH}$ at root-free zone 2 , that was rarely affected by plant roots and their exudates. The leaching events significantly $(\mathrm{P}<0.05)$ reduced EC of rhizosphere and root-free zones in all treatments. This is consistent with findings of Jones et al., (2015), who reported a substantial reduction in EC after leaching events in BRS, as infiltration of BRS by rainfall to lower soluble salt concentrations is one of the basic methods to neutralise residue (Ho et al., 1985). However, comparing EC of different BRS layers in treatments without biochar amendment (CK and DAP) showed an increase in EC from rhizosphere toward root-free zones, while no significant differences were observe between different layers in biochar-amended treatments (DAP+AC and DAP $+\mathrm{PC})$.

The $\mathrm{pH}$ of leachate samples collected from rhizosphere and root-free zones did not show a general trend during five leaching events (Fig. 1). This observation indicated that fertiliser and biochar applications had no significant effect on the buffering capacity of BRS under leached condition. However, this is in contrast with observations of Jones et al. (2012) who reported a decline in leachate $\mathrm{pH}$ by time. The reason may be attributed to the pre-treatment of BRS in our study, before initiating the supplementary leaching experiment, as gypsum pre-treatment would result in 
precipitation of soluble alkalinity as calcium carbonates. It has been also demonstrated by Grafe et al., (2011) that dissolution of solid alkalinity such as desilication product (release of hydroxyl ions into the pore water) may provide $\mathrm{pH}$ buffering and increases $\mathrm{pH}$ between leaching intervals. The presence of alkaline minerals in BRS, such as cancrinite, hydrogarnet and tri-calcium aluminate may act as an alkaline storage and buffer the leachate solution to $\mathrm{pH}$ around 8 (Kong et al., 2018; Xue et al., 2018). On the other hand, the EC of leachate samples collected from both rhizosphere and rootfree zones in current experiment showed a significant $(\mathrm{P}<0.05)$ decrease throughout the leaching events (from day 77 to 105), in all treatments, with higher values in root-free zones than rhizosphere.

\subsection{Nitrogen losses through $\mathrm{NH}_{3}$ volatilisation and leaching process}

Ammonia volatilisation is one of the main pathways of $\mathrm{N}$ loss in alkaline environments (Hayashi et al., 2008). However, $\mathrm{N}$ loss trough $\mathrm{NH}_{3}$ volatilisation in the current experiment was not affected by leaching events as the majority (up to $95 \%$ ) of $\mathrm{NH}_{3}$ loss, from all treatments, occurred within the first three weeks of the study and before the first leaching event at day 77 (Table A.2). Biochar amendment in $\mathrm{DAP}+\mathrm{AC}$ and $\mathrm{DAP}+\mathrm{PC}$ treatments decreased $(\mathrm{P}<0.05)$ cumulative $\mathrm{NH}_{3}$ volatilisation by $80 \%$ and $25 \%$ compared with DAP treatment, respectively. This can be related to the biocharinduced shifts in $\mathrm{BRS} \mathrm{pH}$ and $\mathrm{NH}_{3} / \mathrm{NH}_{4}{ }^{+}$adsorption capacity. Chen et al., (2010) and Philips and Chen (2010) demonstrated that $\mathrm{pH}$ reduction is the most effective approach to reduce $\mathrm{NH}_{3}$ volatilisation, while rehabilitation of BRS through acidification is economically and operationally unfeasible. The high $\mathrm{pH}$ along with lack of organic amendment may reduce $\mathrm{NH}_{4}{ }^{+}$adsorption by BRS and consequently increase $\mathrm{N}$ loss through volatilisation. Therefore, application of biochars, especially with acidic characteristics, can be considered as an alternative rehabilitation strategy in highly alkaline BRS. 
Comparing different treatments under leached and unleached conditions (Table 2) indicated that, although biochar application $(\mathrm{DAP}+\mathrm{AC}$ and $\mathrm{DAP}+\mathrm{PC})$ in unleached condition significantly $(\mathrm{P}<$ 0.05 ) increased $\mathrm{NO}_{3}{ }^{-}$retention in all layers compared with DAP treatment, but could not effectively protect $\mathrm{NO}_{3}{ }^{-}$from being washed out of BRS profile under leaching events. This behaviour is resulted in similar $\mathrm{NO}_{3}{ }^{-}$concentration in all layers of different treatments by the end of experiment. Chen et al., (2010) and Jones et al., (2015) also indicated the high mobility of $\mathrm{NO}_{3}{ }^{-}$in predominantly negative charged BRS, especially in the wet months of the year. The results showed that $\mathrm{NH}_{4}{ }^{+}$ concentration in all layers was only affected by leaching events, while the differences between treatments were not statistically significant (except DAP treatment in rhizosphere that had higher $\mathrm{NH}_{4}{ }^{+}$concentration than other treatments). Leaching process has significantly $(\mathrm{P}<0.05)$ decreased $\mathrm{NH}_{4}{ }^{+}$concentrations in all BRS layers when compared with unleached condition.

The high leaching potential of BRS would result in rapid transport of weakly adsorbed cations and anions from the plants' rhizosphere area (Phillips and Chen, 2010). The leachates $\mathrm{N}$ concentration showed higher $(\mathrm{P}<0.05) \mathrm{NO}_{3}^{-}$loss from $\mathrm{DAP}+\mathrm{AC}$ treatment in both rhizosphere and root-free zones than DAP+PC and DAP treatments (Fig. 2). However, the differences between $\mathrm{NO}_{3}{ }^{-}$concentrations in rhizosphere and root-free zones within each treatment were not statistically significant $(\mathrm{P}>0.05)$. In contrast to $\mathrm{NO}_{3}{ }^{-}$observations, biochar application significantly $(\mathrm{P}<0.05)$ reduced $\mathrm{NH}_{4}{ }^{+}$leaching from $\mathrm{DAP}+\mathrm{AC}$ and $\mathrm{DAP}+\mathrm{PC}$ treatments compared with DAP. There were also no significant differences between $\mathrm{NH}_{4}{ }^{+}$concentrations in rhizosphere and root-free zones within each treatment. The low $\mathrm{NH}_{4}{ }^{+}$concentration in leachates of DAP treatment may be related to the low availability of $\mathrm{NH}_{4}{ }^{+}$for leaching process duo to the high volatilisation rate of DAP treatment in the early days after mineral fertiliser application. 


\subsection{Nutrient losses from bauxite-processing residue sand profile}

The main soluble alkaline components of BRS include: sodium hydroxide $(\mathrm{NaOH})$, sodium carbonate $\left(\mathrm{Na}_{2} \mathrm{CO}_{3}\right)$, sodium bicarbonate $\left(\mathrm{NaHCO}_{3}\right)$, sodium aluminate $\left(\mathrm{NaAl}(\mathrm{OH})_{4}\right)$, sodium silicate $\left(\mathrm{Na}_{2} \mathrm{SiO}_{3}\right)$, potassium hydroxide $(\mathrm{KOH})$, and potassium carbonate $\left(\mathrm{K}_{2} \mathrm{CO}_{3}\right)$. The reduction in concentration of these chemical compounds through leaching process would significantly improve the rehabilitation performance of introduced vegetation cover to unweathered BRS (Clark et al., 2015; Kinnarinen et al., 2015). The cumulative concentrations of several element of interest present in considerable contents in collected leachate samples were measured to identify potential pathways of reduction in nutrient loss associated with biochar amendment to BRS (Table 3). The application of complex organic compounds such as biochar is expected to increase cation exchange capacity of treated BRS. The interaction of applied biochars and plant roots generally decreased nutrient leaching from rhizosphere compared with root-free zones in $\mathrm{DAP}+\mathrm{AC}$ and $\mathrm{DAP}+\mathrm{PC}$ treatments. However, ryegrass roots and their exudates increased nutrient losses from rhizosphere area in DAP and CK treatments in comparison with their root-free zones. Sodium was the dominant soluble cation in the leachate of all treatments, indicating the potential of leaching process to promote sodicity reduction in fresh BRS. The amendment of both $\mathrm{AC}$ and $\mathrm{PC}$ biochars to BRS significantly $(\mathrm{P}<0.05)$ reduced $\mathrm{Na}$ leaching compared with DAP and $\mathrm{CK}$ treatments, while only PC application decreased $(\mathrm{P}<0.05) \mathrm{P}, \mathrm{Ca}$ and $\mathrm{Mg}$ losses in comparison with DAP treatment. On the other hand, $\mathrm{PC}$ application showed significantly higher $(\mathrm{P}<0.05) \mathrm{K}$ and $\mathrm{Al}$ concentrations in collected leachates than $\mathrm{DAP}+\mathrm{AC}$ and DAP treatments during leaching events. The cumulative abundance of exchangeable cations in the leachate samples were in the order of $\mathrm{Na}^{+}>\mathrm{Ca}^{2+}>\mathrm{K}^{+}>\mathrm{Mg}^{2+}>\mathrm{Al}^{3+}$, which is consistent with the study of Xue et al., (2018) who reported the dominance of sodium and calcium cations in the bauxite-processing residue slurry. The higher concentration of an element in leachate of a biocharamended treatment indicates that biochar application increased the bioavailability of that nutrient in BRS. Therefore, it can be concluded that $\mathrm{PC}$ application reduced the bioavailability of $\mathrm{P}, \mathrm{Ca}$ and $\mathrm{Mg}$ 
in the solution phase, while $\mathrm{AC}$ application decreased $\mathrm{K}$ and $\mathrm{Al}$ bioavailability during the experimental period. The variations in leaching behaviour of nutrients can be related to the differences in their chemical forms and texture (Harter, 1991). Jones et al (2011) also reported an increased concentration of extractable $\mathrm{P}, \mathrm{K}$ and $\mathrm{Mg}$ after biosolids and poultry manure application to residue sand. However, the low $\mathrm{P}$ content of the treatments' leachate in the current experiment may also be related to the high $\mathrm{P}$ fixation capacity of $\mathrm{BRS}$ due to its high concentration of $\mathrm{Fe}$ and $\mathrm{Al}$ oxides (Huang et al., 2008). Aluminium rhizotoxicity is considered as one of the main limiting factors of plant growth in fresh bauxite-processing residue (Carter et al., 2008; Woodard et al., 2008), however the findings of the current experiment indicated that AC amendment to BRS may has a potential to reduce the toxic levels of water-soluble Al in the early stages of BRS rehabilitation.

\subsection{Total, dissolved and microbial biomass $C$ and $N$ concentrations of bauxite-processing residue sand profile}

The microbial growth and activity in fresh BRS has been reported to be extremely low due to limited $\mathrm{C}$ availability. However, the rapid development of a diverse microbial community in BRS observed by Banning et al. (2011) suggest that rehabilitation of residue sand embankments may not be limited by the lack of microorganisms able to survive in this alkaline environment. The improvement of microbial activity in BRS is an important factor in promoting a functioning belowground ecosystem, cycling of nutrients through soil organic pools and consequently increasing fertility of the residue sand (Jones et al., 2010). The effect of leaching process on microbial biomass $\mathrm{C}$ concentration in the current experiment was not consistent between different treatments (Table 4). While leaching events have significantly decreased $(\mathrm{P}<0.05) \mathrm{MBC}$ concentrations in all different layers of DAP treatment, there were no significant differences observed on $\mathrm{MBC}$ concentrations in $\mathrm{CK}, \mathrm{DAP}+\mathrm{AC}$ and $\mathrm{DAP}+\mathrm{PC}$ treatments. The MBC concentrations generally decreased from rhizosphere toward rootfree zone 2 in all treatments. In a similar way, leaching events significantly decreased $(\mathrm{P}<0.05)$ 
MBN concentrations in different layers of all treatments (except CK, which showed no differences under leached and unleached conditions). The DAP treatment had highest $(\mathrm{P}<0.05) \mathrm{MBN}$ concentration followed by $\mathrm{DAP}+\mathrm{PC}, \mathrm{DAP}+\mathrm{AC}$ and $\mathrm{CK}$ treatments by the end of experiment.

The DOC concentration in rhizosphere and root-free zones of DAP+AC, DAP and CK treatments generally decreased by leaching process, while its concentration significantly $(\mathrm{P}<0.05)$ increased in $\mathrm{DAP}+\mathrm{PC}$ treatment (Table 5). Comparing different treatments showed that $\mathrm{CK}$ had highest $(\mathrm{P}<0.05)$ DOC concentrations under both leached and unleached conditions followed by DAP + AC, DAP + PC and DAP treatments. Similarly, leaching process decreased $(\mathrm{P}<0.05)$ DON concentrations in all applied treatments and different layers within each treatment (except CK, which showed similar DON concentrations with and without leaching practice). The highest DOC and lowest DON contents in $\mathrm{CK}$ treatment showed the $\mathrm{N}$ limitation for microorganisms and plants growth, while lowest DOC and highest DON contents in biochar-amended treatments indicated the C limitation for the growth of microorganisms and plants, which is consistent with the observed MBC and MBN concentrations of these treatments. The alkaline BRS is able to react with atmospheric $\mathrm{CO}_{2}$ to produce carbonates, which potentially increase the IC concentration over time. However the effect of leaching process on IC concentration in different treatments was not consistent, with increasing effect in DAP and DAP+PC and decreasing effect in $\mathrm{CK}$ and DAP $+\mathrm{AC}$ treatments. The highest concentration of IC in leached and unleached conditions were observed in DAP and CK treatments, respectively.

The leaching process significantly $(\mathrm{P}<0.05)$ decreased total $\mathrm{N}$ content in all fertiliser and biochar applied treatments (DAP, DAP $+\mathrm{AC}$ and $\mathrm{DAP}+\mathrm{PC}$ ), while the differences between total $\mathrm{N}$ concentration under leached and unleached conditions were not statistically significant in CK treatment (Table 6). The combined application of AC with mineral fertiliser showed the highest (P< $0.05)$ total $\mathrm{N}$ concentration among all treatments, while $\mathrm{CK}$ had the lowest $(\mathrm{P}<0.05)$ total $\mathrm{N}$ content by the end of experiment. The total $\mathrm{C}$ concentration of different treatments were not generally 
affected by leaching process (except a significant decrease $(\mathrm{P}<0.05)$ in root-free zones of $\mathrm{DAP}+\mathrm{AC})$. However, similar to the total $\mathrm{N}$, the highest and lowest $(\mathrm{P}<0.05)$ total $\mathrm{C}$ contents in all rhizosphere and root-free zones observed in $\mathrm{DAP}+\mathrm{AC}$ and $\mathrm{CK}$ treatments, respectively.

\subsection{Plant biomass and nitrogen uptake as affected by biochar amendment and leaching process}

Leaching process was able to reduce the salinity of BRS to levels lower than the critical threshold for imitating plant growth in saline soils. Leaching has significantly $(\mathrm{P}<0.05)$ increased ryegrass shoot biomass, with highest biomass was observed in DAP $+\mathrm{AC}$ treatment followed by DAP $+\mathrm{PC}$, DAP and

CK treatments, respectively (Table 7). This is in agreement with the findings of Kaur et al., (2016) that observed a higher biomass production form kikuyu grass under leached condition and acidification of BRS. Goloran et al., $(2015,2014)$ also reported a significant inverse relationship between $\mathrm{pH}$ and biomass production of plants grown in BRS. Leaching would also reduce the phytotoxic compounds in alkaline bauxite-processing residue, such as high contents of $\mathrm{HCO}_{3}{ }^{-} / \mathrm{CO}_{3}{ }^{2-}$ and aluminate ions (Courtney and Kirwan, 2012), resulting a sustainable environment for optimum plant growth. In a similar way, leaching process has increased $(\mathrm{P}<0.05)$ treatments' root biomass with higher values in $\mathrm{DAP}+\mathrm{AC}$ and $\mathrm{DAP}+\mathrm{PC}$ treatments than $\mathrm{DAP}$ and $\mathrm{CK}$ treatments. These observations consequently resulted in lower shoot / root biomass ratios in leached than unleached condition.

Leaching process resulted in significantly $(\mathrm{P}<0.05)$ higher root length with highest and lowest values at $\mathrm{DAP}+\mathrm{PC}$ and DAP treatments, respectively. The plant biomass / root length ratio was also higher in $\mathrm{N}$ applied treatments than $\mathrm{CK}$ by the end of experiment. Although plant $\mathrm{N}$ concentration was significantly $(\mathrm{P}<0.05)$ lower under leached condition, but the differences between total plant $\mathrm{N}$ uptakes under leached and unleached conditions were not statistically significant. Finally, the highest 
plant $\mathrm{N}$ uptake observed in $\mathrm{DAP}+\mathrm{AC}$ followed by $\mathrm{DAP}+\mathrm{PC}$, DAP and $\mathrm{CK}$ treatments, with no significant difference between leached and unleached conditions. This observation is in contrast with findings of Kaur et al., (2016) who reported an enhancement in $\mathrm{N}$ uptake by kikuyu grass due to leaching of excess salts and alkalinity from the residue profile. These findings suggest the great potential of supplementary leaching process along with organic material amendments to optimise plants' rhizosphere management for sustainable vegetation performance in fresh bauxite-processing residue sand.

\section{Conclusion}

Successful revegetation of a bauxite-processing residue disposal area is highly dependent on improving its nutrient retention capacity as well as the proper amelioration of its highly saline and alkaline environment. This study has demonstrated the important role of biochar amendment and supplementary leaching process in improving unweathered BRS' rhizosphere biochemical properties. The amendment of acidic and alkaline biochars to BRS reduced $\mathrm{N}$ loss $\left(\mathrm{NH}_{3}\right.$ volatilisation) and increased $\mathrm{N}$ retention capacity (TN and DON) in ryegrass rhizosphere. Sodium was the dominant exchangeable cation of BRS and the cumulative concentration of leached cations were in the order of $\mathrm{Na}^{+}>\mathrm{Ca}^{2+}>\mathrm{K}^{+}>\mathrm{Mg}^{2+}$. Supplementary leaching process successfully reduced BRS salinity by ca. $62 \%$ in biochar-amended treatments, while the $\mathrm{pH}$ values remained unchanged (ca. 8). These changes have resulted in a more favourable environment for ryegrass above- and below-ground growth and consequently improved BRS rehabilitation performance. Therefore, the application of organic amendments (such as biochar) to fresh BRS, followed by optimum supplementary leaching process prove to be an efficient rhizosphere management strategy for establishment of a sustainable ecosystem on residue storage areas as part of progressive closure. These findings would also provide an excellent baseline information for assessing the effect of organic amendments on reducing the potential environmental risks associated with alkaline wastes' disposal strategies. 


\section{Acknowledgments}

This research was supported under the Australian Research Council's Linkage Projects funding scheme (LP0989670) and by Alcoa World Alumina, Australia. Professor Chengrong Chen is the recipient of an Australian Research Council Future Fellowship (FT0990547).

\section{References}

Banning, N.C., Phillips, I.R., Jones, D.L., Murphy, D. V., 2011. Development of Microbial Diversity and Functional Potential in Bauxite Residue Sand under Rehabilitation. Restor. Ecol. 19, 78-87. doi:10.1111/j.1526-100X.2009.00637.x

Carter, C.M., van der Sloot, H.A., Cooling, D., van Zomeren, A., Matheson, T., 2008.

Characterization of untreated and neutralized bauxite residue for improved waste management. Environ. Eng. Sci. 25, 475-488. doi:10.1089/ees.2006.0234

Chen, C.R., Phillips, I.R., Wei, L.L., Xu, Z.H., 2010. Behaviour and dynamics of di-ammonium phosphate in bauxite processing residue sand in Western Australia-I. NH3 volatilisation and residual nitrogen availability. Environ. Sci. Pollut. Res. 17, 1098-1109. doi:10.1007/s11356009-0267-5

Clark, M.W., Johnston, M., Reichelt-Brushett, A.J., 2015. Comparison of several different neutralisations to a bauxite refinery residue: Potential effectiveness environmental ameliorants. Appl. Geochemistry 56, 1-10. doi:10.1016/J.APGEOCHEM.2015.01.015

Courtney, R., Kirwan, L., 2012. Gypsum amendment of alkaline bauxite residue - Plant available aluminium and implications for grassland restoration. Ecol. Eng. 42, 279-282. doi:10.1016/J.ECOLENG.2012.02.025

Courtney, R.G., Jordan, S.N., Harrington, T., 2009. Physico-chemical changes in bauxite residue following application of spent mushroom compost and gypsum. L. Degrad. Dev. 20, 572-581. doi:10.1002/ldr.926

Gahoonia, T.S., 1993. Influence of root-induced $\mathrm{pH}$ on the solubility of soil aluminium in the 
rhizosphere. Plant Soil 149, 289-291. doi:10.1007/BF00016620

Goloran, J.B., Chen, C.R., Phillips, I.R., Liu, X., 2015. Transformation and plant uptake of 15Nlabeled fertilizers mediated by ammonia-oxidizing bacteria in alkaline bauxite-processing residue sand amended with greenwaste compost. Ecol. Eng. 74, 68-78. doi:10.1016/J.ECOLENG.2014.09.118

Goloran, J.B., Chen, C.R., Phillips, I.R., Xu, Z.H., Condron, L.M., 2014. Plant phosphorus availability index in rehabilitated bauxite-processing residue sand. Plant Soil 374, 565-578. doi:10.1007/s11104-013-1900-0

Grafe, M., Power, G., Klauber, C., 2011. Bauxite residue issues: III. Alkalinity and associated chemistry. Hydrometallurgy 108, 60-79. doi:10.1016/J.HYDROMET.2011.02.004

Gwenzi, W., Hinz, C., Holmes, K., Phillips, I.R., Mullins, I.J., 2011. Field-scale spatial variability of saturated hydraulic conductivity on a recently constructed artificial ecosystem. Geoderma 166, 43-56. doi:10.1016/J.GEODERMA.2011.06.010

Harter, R.D., 1991. Micronutrient adsorption-desorption reactions in soils, in: Micronutrients in Agriculture. Soil Science Society of America, Madison, pp. 59-88.

Hayashi, K., Nishimura, S., Yagi, K., 2008. Ammonia volatilization from a paddy field following applications of urea: Rice plants are both an absorber and an emitter for atmospheric ammonia. Sci. Total Environ. 390, 485-494. doi:10.1016/J.SCITOTENV.2007.10.037

Hedley, M.J., Nye, P.H., White, R.E., 1982. Plant induced changes in the rhizosphere of rape (Brassica napus var. Emerald) seedlings. II. Origin of the pH change. New Phytol. 91, 31-44.

Ho, G.E., Newman, P.W.G., Mathew, K., De Potter, H., 1985. Neutralisation of bauxite processing residue with copperas. Proceedings of the 13th Australian Chemical Engineering Conference, Perth, Western Australia. Institution of Engineers, Australia, pp. 103-108.

Huang, W., Wang, S., Zhu, Z., Li, L., Yao, X., Rudolph, V., Haghseresht, F., 2008. Phosphate removal from wastewater using red mud. J. Hazard. Mater. 158, 35-42. doi:10.1016/J.JHAZMAT.2008.01.061

Jones, B.E.H., Haynes, R.J., Phillips, I.R., 2010. Effect of amendment of bauxite processing sand with organic materials on its chemical, physical and microbial properties. J. Environ. Manage. 91, 2281-2288. doi:10.1016/j.jenvman.2010.06.013 
Jones, B.E.H., Haynes, R.J., Phillips, I.R., 2011. Influence of organic waste and residue mud additions on chemical, physical and microbial properties of bauxite residue sand. Environ. Sci. Pollut. Res. 18, 199-211. doi:10.1007/s11356-010-0364-5

Jones, B.E.H., Haynes, R.J., Phillips, I.R., 2012. Cation and anion leaching and growth of Acacia saligna in bauxite residue sand amended with residue mud, poultry manure and phosphogypsum. Environ. Sci. Pollut. Res. 19, 835-846. doi:10.1007/s11356-011-0630-1

Jones, B.E.H., Haynes, R.J., Phillips, I.R., 2015. Influence of amendments on acidification and leaching of $\mathrm{Na}$ from bauxite processing sand. Ecol. Eng. 84, 435-442. doi:10.1016/J.ECOLENG.2015.09.054

Kaur, N., Phillips, I., Fey, M.V., 2016. Amelioration of bauxite residue sand by intermittent additions of nitrogen fertiliser and leaching fractions: The effect on growth of kikuyu grass and fate of applied nutrients. Sci. Total Environ. 550, 362-371.

doi:10.1016/J.SCITOTENV.2016.01.012

Kinnarinen, T., Lubieniecki, B., Holliday, L., Helsto, J.-J., Häkkinen, A., 2015. Recovery of sodium from bauxite residue by pressure filtration and cake washing. Int. J. Miner. Process. 141, 20-26. doi:10.1016/J.MINPRO.2015.06.006

Kong, X., Jiang, X., Xue, S., Huang, L., Hartley, W., Wu, C., Li, X., 2018. Migration and distribution of saline ions in bauxite residue during water leaching. Trans. Nonferrous Met. Soc. China 28, 534-541. doi:10.1016/S1003-6326(18)64686-2

Kong, X., Tian, T., Xue, S., Hartley, W., Huang, L., Wu, C., Li, C., 2018. Development of alkaline electrochemical characteristics demonstrates soil formation in bauxite residue undergoing natural rehabilitation. L. Degrad. Dev. 29, 58-67. doi:10.1002/1dr.2836

Liao, J., Jiang, J., Xue, S., Qingyu, C., Wu, H., Manikandan, R., Hartley, W., Huang, L., 2018. A novel acid-producing fungus isolated from bauxite residue: the potential to reduce the alkalinity. Geomicrobiol. J. 35, 840-847. doi:10.1080/01490451.2018.1479807

Munshower, F.F., 1994. Practical handbook of disturbed land revegetation. CRC Press, Boca Raton.

Phillips, I.R., Chen, C., 2010. Surface charge characteristics and sorption properties of bauxiteprocessing residue sand. Aust. J. Soil Res. 48, 77-87. doi:10.1071/SR09056

Thiyagarajan, C., Bell, R.W., Anderson, J.D., Phillips, I., 2011. Zinc forms in compost and red mud- 
amended bauxite residue sand. J. Soils Sediments 11, 101-114. doi:10.1007/s11368-010-0279-2

Woodard, H.J., Hossner, L., Bush, J., 2008. Ameliorating caustic properties of aluminum extraction residue to establish a vegetative cover. J. Environ. Sci. Heal. Part A 43, 1157-1166. doi:10.1080/10934520802171659

Xu, G., Ding, X., Kuruppu, M., Zhou, W., Biswas, W., 2018. Research and application of nontraditional chemical stabilizers on bauxite residue (red sand) dust control, a review. Sci. Total Environ. 616-617, 1552-1565. doi:10.1016/J.SCITOTENV.2017.10.158

Xue, S., Li, M., Jiang, J., Millar, G.J., Li, C., Kong, X., 2018. Phosphogypsum stabilization of bauxite residue: Conversion of its alkaline characteristics. J. Environ. Sci. doi:10.1016/J.JES.2018.05.016

Zhang, R., Zheng, S., Ma, S., Zhang, Y., 2011. Recovery of alumina and alkali in Bayer red mud by the formation of andradite-grossular hydrogarnet in hydrothermal process. J. Hazard. Mater. 189, 827-835. doi:10.1016/J.JHAZMAT.2011.03.004

Zhu, F., Cheng, Q., Xue, S., Li, C., Hartley, W., Wu, C., Tian, T., 2018. Influence of natural regeneration on fractal features of residue microaggregates in bauxite residue disposal areas. $\mathrm{L}$. Degrad. Dev. 29, 138-149. doi:10.1002/1dr.2848

Zhu, F., Hou, J., Xue, S., Wu, C., Wang, Q., Hartley, W., 2017. Vermicompost and Gypsum Amendments Improve Aggregate Formation in Bauxite Residue. L. Degrad. Dev. 28, 2109 2120. doi:10.1002/ldr.2737

Zhu, F., Liao, J., Xue, S., Hartley, W., Zou, Q., Wu, H., 2016. Evaluation of aggregate microstructures following natural regeneration in bauxite residue as characterized by synchrotron-based X-ray micro-computed tomography. Sci. Total Environ. 573, 155-163. doi:10.1016/J.SCITOTENV.2016.08.108 

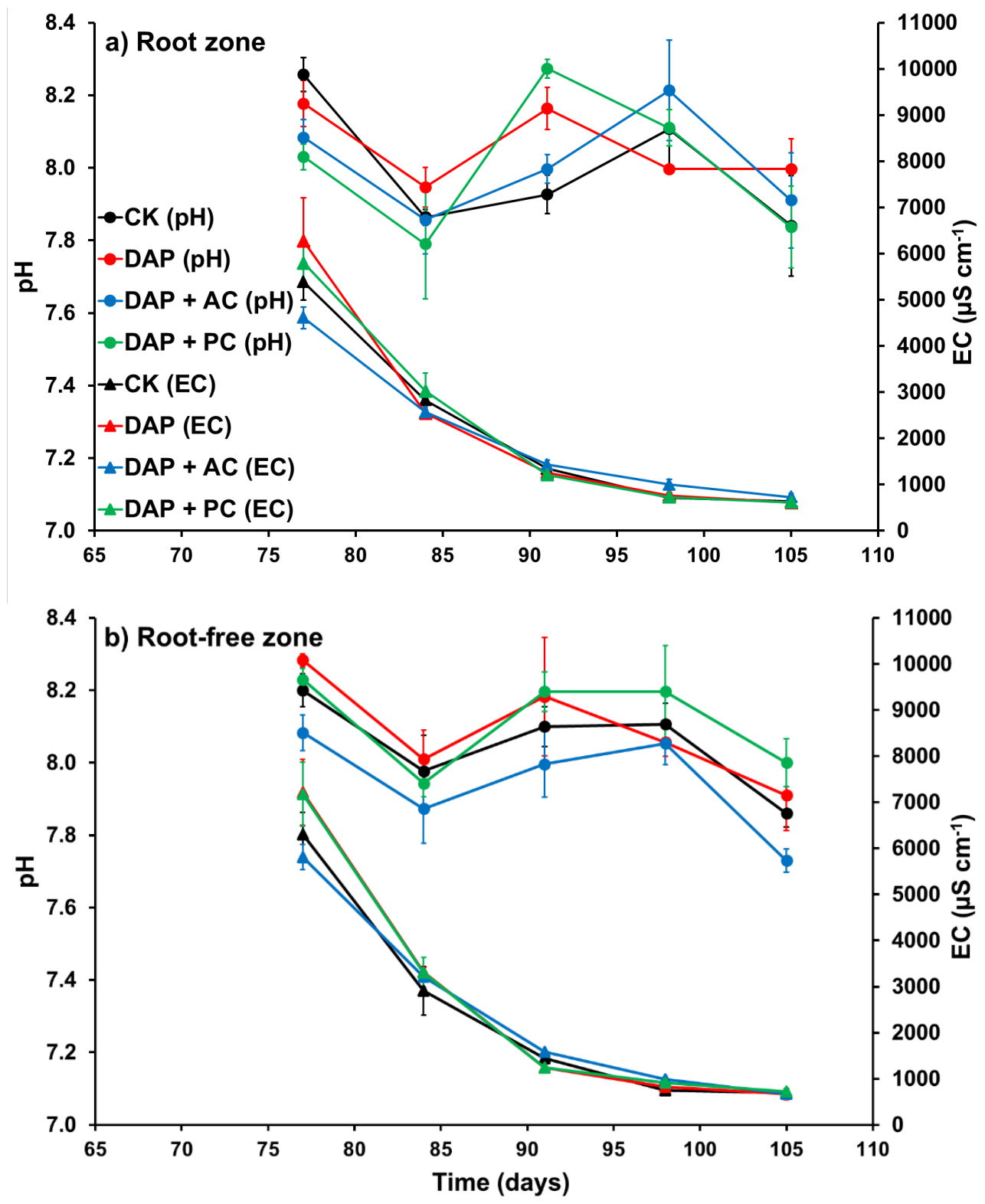

Fig.1. $\mathrm{pH}$ and EC of leachate from root zone (a) and root-free zone (b) during the leaching events. Vertical bars are standard error of three replicates. $\mathrm{CK}=$ Control; DAP $=$ Di-ammonium phosphate; $\mathrm{DAP}+\mathrm{AC}=$ Di-ammonium phosphate + acidic aged biochar; DAP $+\mathrm{PC}=$ Di-ammonium phosphate + pine biochar. 

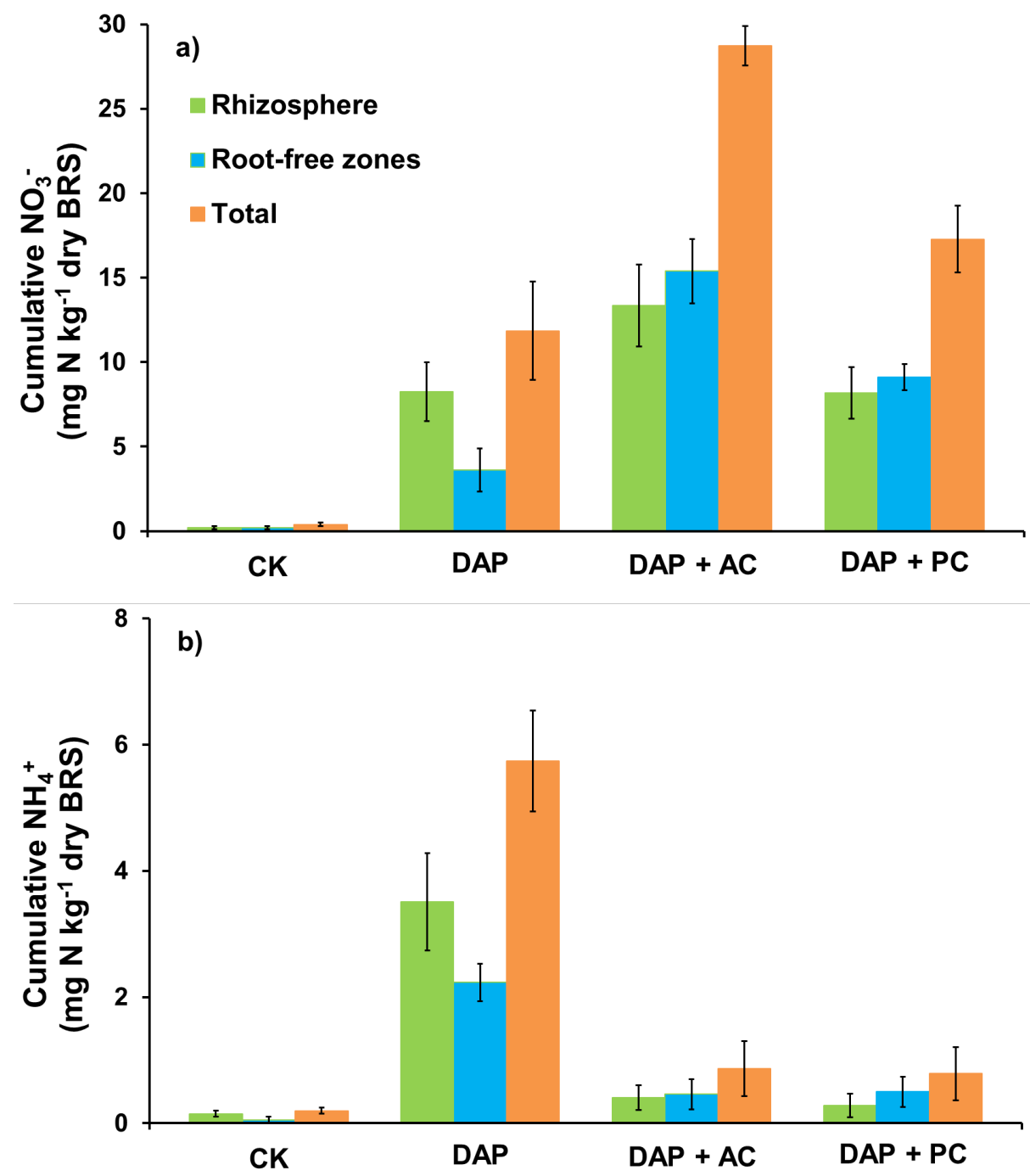

Fig.2. Cumulative $\mathrm{NO}_{3}{ }^{-}-\mathrm{N}$ (a) and $\mathrm{NH}_{4}{ }^{+}-\mathrm{N}$ (b) concentrations in leachates collected from rhizosphere and root-free zones. Vertical bars are standard error of three replicates. The value reported for rootfree zones is the combined concentration of both root-free zone 1 and root-free zone 2 . $\mathrm{CK}=$ Control; DAP $=$ Di-ammonium phosphate; DAP $+\mathrm{AC}=$ Di-ammonium phosphate + acidic aged biochar; DAP + PC $=$ Di-ammonium phosphate + pine biochar. 
Table 1: The $\mathrm{pH}$ and EC at rhizosphere and root-free zones

\begin{tabular}{|c|c|c|c|c|c|c|c|}
\hline \multicolumn{2}{|c|}{ Treatment } & \multirow{2}{*}{$\begin{array}{l}\mathrm{pH} \\
(\mathrm{RZ})\end{array}$} & \multirow{2}{*}{$\begin{array}{l}\mathrm{pH} \\
(\mathrm{RFZ1})\end{array}$} & \multirow{2}{*}{$\begin{array}{l}\mathrm{pH} \\
\text { (RFZ2) }\end{array}$} & \multirow{2}{*}{$\begin{array}{l}\begin{array}{l}\mathrm{EC} \\
\mu \mathrm{cm}^{-1} \\
(\mathrm{RZ})\end{array} \\
250.3 \mathrm{a}\end{array}$} & \multirow{2}{*}{$\begin{array}{l}\mathrm{EC} \\
\mu \mathrm{s} \mathrm{cm}^{-1} \\
(\mathrm{RFZ1})\end{array}$} & \multirow{2}{*}{$\begin{array}{l}\begin{array}{l}\mathrm{EC} \\
\mu \mathrm{s} \mathrm{cm}^{-1} \\
(\mathrm{RFZ2})\end{array} \\
348.0 \mathrm{a}\end{array}$} \\
\hline & CK & & & & & & \\
\hline \multirow{4}{*}{ Unleached } & DAP & $8.19 \mathrm{bc}$ & $8.16 \mathrm{bc}$ & $8.18 \mathrm{c}$ & $266.3 \mathrm{a}$ & $305.7 \mathrm{a}$ & $297.7 \mathrm{ab}$ \\
\hline & $\mathrm{DAP}+\mathrm{AC}$ & $7.76 \mathrm{e}$ & $7.81 \mathrm{~d}$ & $7.89 \mathrm{e}$ & $266.7 \mathrm{a}$ & $207.4 \mathrm{c}$ & $240.9 \mathrm{~b}$ \\
\hline & $\mathrm{DAP}+\mathrm{PC}$ & $8.54 \mathrm{a}$ & $8.57 \mathrm{a}$ & $8.54 \mathrm{a}$ & $248.0 \mathrm{a}$ & $231.0 \mathrm{bc}$ & $248.0 \mathrm{~b}$ \\
\hline & $\mathrm{CK}$ & $8.10 \mathrm{~cd}$ & $8.12 \mathrm{c}$ & $8.12 \mathrm{~cd}$ & $80.8 \mathrm{~d}$ & $79.3 \mathrm{e}$ & $82.2 \mathrm{~d}$ \\
\hline \multirow{3}{*}{ Leached } & DAP & $8.04 \mathrm{~d}$ & $8.13 b c$ & $8.12 \mathrm{~cd}$ & $82.9 \mathrm{~cd}$ & $84.2 \mathrm{de}$ & $82.4 \mathrm{~d}$ \\
\hline & $\mathrm{DAP}+\mathrm{AC}$ & $8.14 \mathrm{bcd}$ & $8.10 \mathrm{c}$ & $8.09 \mathrm{~d}$ & $102.7 \mathrm{~b}$ & $106.0 \mathrm{~d}$ & $106.4 \mathrm{c}$ \\
\hline & $\mathrm{DAP}+\mathrm{PC}$ & $8.24 \mathrm{~b}$ & $8.21 \mathrm{bc}$ & $8.28 \mathrm{~b}$ & $95.1 \mathrm{bc}$ & $95.9 \mathrm{de}$ & $100.1 \mathrm{~cd}$ \\
\hline
\end{tabular}

\footnotetext{
Means followed by different letters within a column indicate significant differences between the treatments at $P<0.05 . \mathrm{CK}=\mathrm{Control}$; $\mathrm{DAP}=\mathrm{Di}$-ammonium phosphate; $\mathrm{DAP}+\mathrm{AC}=\mathrm{Di}$-ammonium phosphate + acidic aged biochar; DAP + PC $=$ Di-ammonium phosphate + pine biochar; WHC $=$ Water holding capacity; RZ = Rhizosphere; RFZ1 = Root-free zone 1; RFZ2 = Root-free zone 2.
} 
Table 2: The $\mathrm{NO}_{3}{ }^{-}-\mathrm{N}$ and $\mathrm{NH}_{4}{ }^{+}-\mathrm{N}$ concentrations at rhizosphere and root-free zones

\begin{tabular}{|c|c|c|c|c|c|c|c|}
\hline \multicolumn{2}{|c|}{ Treatment } & \multirow{2}{*}{ 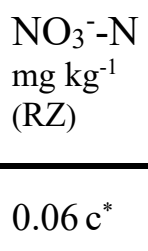 } & \multirow{2}{*}{$\begin{array}{l}\mathrm{NO}_{3}^{-}-\mathrm{N} \\
\mathrm{mg} \mathrm{kg}^{-1} \\
(\mathrm{RFZ1})\end{array}$} & \multirow{2}{*}{$\begin{array}{l}\mathrm{NO}_{3}{ }^{-}-\mathrm{N} \\
\mathrm{mg} \mathrm{kg}^{-1} \\
(\mathrm{RFZ2})\end{array}$} & \multirow{2}{*}{$\begin{array}{l}\begin{array}{l}\mathrm{NH}_{4}{ }^{+}-\mathrm{N} \\
\mathrm{mg} \mathrm{kg}^{-1} \\
(\mathrm{RZ})\end{array} \\
5.01 \mathrm{~b}\end{array}$} & \multirow{2}{*}{$\begin{array}{l}\begin{array}{l}\mathrm{NH}_{4}{ }^{+}-\mathrm{N} \\
\mathrm{mg} \mathrm{kg}^{-1} \\
(\mathrm{RFZ1})\end{array} \\
5.30 \mathrm{ab}\end{array}$} & \multirow{2}{*}{$\begin{array}{l}\mathrm{NH}_{4}{ }^{+}-\mathrm{N} \\
\mathrm{mg} \mathrm{kg}^{-1} \\
(\mathrm{RFZ2})\end{array}$} \\
\hline & $\mathrm{CK}$ & & & & & & \\
\hline \multirow{4}{*}{ Unleached } & DAP & $10.24 \mathrm{~b}$ & $12.82 \mathrm{~b}$ & $13.31 \mathrm{~b}$ & $6.26 \mathrm{a}$ & $5.80 \mathrm{a}$ & $5.89 \mathrm{a}$ \\
\hline & $\mathrm{DAP}+\mathrm{AC}$ & $29.84 \mathrm{a}$ & $26.83 \mathrm{a}$ & $27.42 \mathrm{a}$ & $5.00 \mathrm{~b}$ & $4.38 \mathrm{c}$ & $5.10 \mathrm{ab}$ \\
\hline & $\mathrm{DAP}+\mathrm{PC}$ & $30.01 \mathrm{a}$ & $28.66 \mathrm{a}$ & $32.19 \mathrm{a}$ & $5.11 \mathrm{~b}$ & $5.64 \mathrm{a}$ & $5.38 \mathrm{ab}$ \\
\hline & $\mathrm{CK}$ & $0.01 \mathrm{c}$ & $0.01 \mathrm{c}$ & $0.01 \mathrm{c}$ & $4.56 \mathrm{bc}$ & $4.53 \mathrm{bc}$ & $4.12 b$ \\
\hline \multirow{3}{*}{ Leached } & DAP & $0.01 \mathrm{c}$ & $0.01 \mathrm{c}$ & $0.01 \mathrm{c}$ & $5.08 \mathrm{~b}$ & $3.91 \mathrm{c}$ & $4.60 \mathrm{ab}$ \\
\hline & $\mathrm{DAP}+\mathrm{AC}$ & $0.01 \mathrm{c}$ & $0.01 \mathrm{c}$ & $0.01 \mathrm{c}$ & $3.86 \mathrm{c}$ & $4.32 \mathrm{c}$ & $4.17 \mathrm{~b}$ \\
\hline & $\mathrm{DAP}+\mathrm{PC}$ & $0.01 \mathrm{c}$ & $0.01 \mathrm{c}$ & $0.01 \mathrm{c}$ & $4.60 \mathrm{bc}$ & $4.30 \mathrm{c}$ & $4.63 \mathrm{ab}$ \\
\hline
\end{tabular}

\footnotetext{
${ }^{*}$ Means followed by different letters within a column indicate significant differences between the treatments at $P<0.05 . \mathrm{CK}=\mathrm{Control} ; \mathrm{DAP}=\mathrm{Di}$-ammonium phosphate; $\mathrm{DAP}+\mathrm{AC}=\mathrm{Di}$-ammonium phosphate + acidic aged biochar; DAP + PC $=$ Di-ammonium phosphate + pine biochar; WHC $=$ Water holding capacity; RZ = Rhizosphere; RFZ1 = Root-free zone 1; RFZ2 = Root-free zone 2 .
} 
Table 3: The cumulative nutrient concentrations in leachates collected from rhizosphere and root-free zones

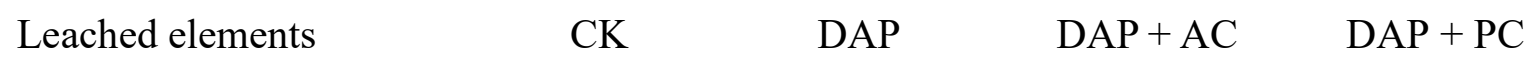

\begin{tabular}{|c|c|c|c|c|c|}
\hline & Rhizosphere & $0.01 \mathrm{c}^{* * *}$ & $0.07 \mathrm{a}$ & $0.05 \mathrm{ab}$ & $0.03 \mathrm{bc}$ \\
\hline \multirow[t]{3}{*}{$\mathrm{P}^{*}$} & Root-free zones** & $0.01 \mathrm{c}$ & $0.04 \mathrm{ab}$ & $0.05 \mathrm{a}$ & $0.04 \mathrm{~b}$ \\
\hline & Total & $0.02 \mathrm{c}$ & $0.11 \mathrm{a}$ & $0.10 \mathrm{a}$ & $0.07 \mathrm{~b}$ \\
\hline & Rhizosphere & $3.9 \mathrm{~b}$ & $7.8 \mathrm{~b}$ & $4.0 \mathrm{~b}$ & $13.4 \mathrm{a}$ \\
\hline \multirow[t]{3}{*}{$\mathrm{K}$} & Root-free zones & $2.7 \mathrm{c}$ & $4.3 \mathrm{~b}$ & $5.4 \mathrm{~b}$ & $22.1 \mathrm{a}$ \\
\hline & Total & $6.6 \mathrm{c}$ & $12.1 \mathrm{~b}$ & $9.4 \mathrm{~b}$ & $35.5 \mathrm{a}$ \\
\hline & Rhizosphere & $39.9 \mathrm{~b}$ & $85.8 \mathrm{a}$ & $82.1 \mathrm{a}$ & $34.8 \mathrm{~b}$ \\
\hline \multirow[t]{3}{*}{$\mathrm{Ca}$} & Root-free zones & $26.2 \mathrm{c}$ & $46.2 \mathrm{~b}$ & $78.4 \mathrm{a}$ & $42.0 \mathrm{~b}$ \\
\hline & Total & $66.1 \mathrm{~b}$ & $132.0 \mathrm{a}$ & $160.5 \mathrm{a}$ & $76.8 \mathrm{~b}$ \\
\hline & Rhizosphere & $1.5 \mathrm{ab}$ & $1.7 \mathrm{a}$ & $1.7 \mathrm{a}$ & $0.8 \mathrm{~b}$ \\
\hline \multirow[t]{3}{*}{$\mathrm{Mg}$} & Root-free zones & $1.0 \mathrm{~b}$ & $0.9 \mathrm{~b}$ & $1.6 \mathrm{a}$ & $1.0 \mathrm{~b}$ \\
\hline & Total & $2.5 \mathrm{ab}$ & $2.6 \mathrm{ab}$ & $3.3 \mathrm{a}$ & $1.8 \mathrm{~b}$ \\
\hline & Rhizosphere & $347.0 \mathrm{a}$ & $372.6 \mathrm{a}$ & $200.4 b$ & $167.4 \mathrm{~b}$ \\
\hline \multirow[t]{3}{*}{$\mathrm{Na}$} & Root-free zones & $206.8 \mathrm{ab}$ & $186.9 \mathrm{~b}$ & $200.8 \mathrm{~b}$ & $256.2 \mathrm{a}$ \\
\hline & Total & $553.8 \mathrm{a}$ & $559.5 \mathrm{a}$ & $401.2 \mathrm{~b}$ & $423.6 \mathrm{~b}$ \\
\hline & Rhizosphere & $0.07 \mathrm{a}$ & $0.07 \mathrm{a}$ & $0.05 \mathrm{a}$ & $0.07 \mathrm{a}$ \\
\hline \multirow[t]{2}{*}{ Al } & Root-free zones & $0.05 \mathrm{~b}$ & $0.04 \mathrm{~b}$ & $0.03 \mathrm{~b}$ & $0.09 \mathrm{a}$ \\
\hline & Total & $0.12 \mathrm{~b}$ & $0.11 \mathrm{~b}$ & $0.08 \mathrm{~b}$ & $0.16 \mathrm{a}$ \\
\hline
\end{tabular}

* Cumulative concentrations of five leaching event reported according to $\mathrm{mg} \mathrm{kg}^{-1}$ dry BRS weight. ${ }^{* *}$ The value reported for root-free zones is the combined concentration of both root-free zone 1 and root-free zone 2. ${ }^{* * *}$ Means followed by different letters within a row indicate significant differences between the treatments at $P<0.05$. CK $=$ Control; DAP $=$ Di-ammonium phosphate; DAP $+\mathrm{AC}=$ Di-ammonium phosphate + acidic aged biochar; DAP $+\mathrm{PC}=$ Di-ammonium phosphate + pine biochar. 
Table 4: Microbial biomass $\mathrm{C}$ and $\mathrm{N}$ concentrations at rhizosphere and root-free zones

\begin{tabular}{|c|c|c|c|c|c|c|c|}
\hline \multicolumn{2}{|c|}{ Treatment } & $\begin{array}{c}\mathrm{MBC} \\
\mathrm{mg} \mathrm{kg}^{-1} \\
(\mathrm{RZ})\end{array}$ & $\begin{array}{l}\mathrm{MBC} \\
\mathrm{mg} \mathrm{kg}^{-1} \\
(\mathrm{RFZ1})\end{array}$ & $\begin{array}{l}\mathrm{MBC} \\
\mathrm{mg} \mathrm{kg}^{-1} \\
(\mathrm{RFZ2})\end{array}$ & $\begin{array}{l}\mathrm{MBN} \\
\mathrm{mg} \mathrm{kg}^{-1} \\
(\mathrm{RZ})\end{array}$ & $\begin{array}{l}\mathrm{MBN} \\
\mathrm{mg} \mathrm{kg}^{-1} \\
(\mathrm{RFZ1})\end{array}$ & $\begin{array}{l}\mathrm{MBN} \\
\mathrm{mg} \mathrm{kg}^{-1} \\
(\mathrm{RFZ2})\end{array}$ \\
\hline \multirow{4}{*}{ Unleached } & CK & $3.6 \mathrm{~d}^{*}$ & $2.0 \mathrm{e}$ & $1.1 \mathrm{e}$ & $0.6 \mathrm{e}$ & $0.4 \mathrm{f}$ & $0.3 \mathrm{f}$ \\
\hline & DAP & $83.0 \mathrm{a}$ & $62.4 \mathrm{a}$ & $59.1 \mathrm{a}$ & $12.7 \mathrm{a}$ & $9.7 \mathrm{a}$ & $7.1 \mathrm{a}$ \\
\hline & $\mathrm{DAP}+\mathrm{AC}$ & $29.1 \mathrm{c}$ & $15.2 \mathrm{~d}$ & $10.0 \mathrm{de}$ & $9.0 \mathrm{~b}$ & $7.8 \mathrm{~b}$ & $5.2 \mathrm{~b}$ \\
\hline & $\mathrm{DAP}+\mathrm{PC}$ & $32.3 \mathrm{c}$ & $25.5 \mathrm{c}$ & $24.2 \mathrm{bc}$ & $8.0 \mathrm{~b}$ & $6.1 \mathrm{c}$ & $4.4 \mathrm{bc}$ \\
\hline \multirow{4}{*}{ Leached } & CK & $10.2 \mathrm{~d}$ & $8.0 \mathrm{e}$ & $5.4 \mathrm{e}$ & $0.6 \mathrm{e}$ & $0.4 \mathrm{f}$ & $0.3 \mathrm{f}$ \\
\hline & DAP & $65.1 \mathrm{~b}$ & $52.3 \mathrm{~b}$ & $33.6 \mathrm{~b}$ & $6.1 \mathrm{c}$ & $4.4 \mathrm{~d}$ & $3.5 \mathrm{~cd}$ \\
\hline & $\mathrm{DAP}+\mathrm{AC}$ & $29.4 \mathrm{c}$ & $24.5 \mathrm{c}$ & $18.2 \mathrm{~cd}$ & $3.2 \mathrm{~d}$ & $2.4 \mathrm{e}$ & $1.1 \mathrm{ef}$ \\
\hline & $\mathrm{DAP}+\mathrm{PC}$ & $36.5 \mathrm{c}$ & $28.6 \mathrm{c}$ & $24.3 \mathrm{bc}$ & $4.5 \mathrm{~d}$ & $3.4 \mathrm{de}$ & $2.3 \mathrm{de}$ \\
\hline
\end{tabular}

\footnotetext{
* Means followed by different letters within a column indicate significant differences between the treatments at $P<0.05 . \mathrm{CK}=\mathrm{Control} ; \mathrm{DAP}=\mathrm{Di}$-ammonium phosphate; $\mathrm{DAP}+\mathrm{AC}=\mathrm{Di}$-ammonium phosphate + acidic aged biochar; DAP + PC $=$ Di-ammonium phosphate + pine biochar; WHC $=$ Water holding capacity; $\mathrm{MBC}=$ Microbial biomass $\mathrm{C} ; \mathrm{MBN}=$ Microbial biomass $\mathrm{N} ; \mathrm{RZ}=$ Rhizosphere; RFZ1 = Root-free zone 1; RFZ2 = Root-free zone 2.
} 
Table 5: Dissolved organic $\mathrm{C}$ and $\mathrm{N}$ and inorganic $\mathrm{C}$ concentrations at rhizosphere and root-free zones

\begin{tabular}{|c|c|c|c|c|c|c|c|c|c|c|}
\hline \multicolumn{2}{|c|}{ Treatment } & $\begin{array}{l}\mathrm{DOC} \\
\mathrm{mg} \mathrm{kg}^{-1} \\
(\mathrm{RZ})\end{array}$ & $\begin{array}{l}\text { DOC } \\
\mathrm{mg} \mathrm{kg}^{-1} \\
(\mathrm{RFZ1})\end{array}$ & $\begin{array}{l}\text { DOC } \\
\mathrm{mg} \mathrm{kg}^{-1} \\
\text { (RFZ2) }\end{array}$ & $\begin{array}{l}\text { DON } \\
\mathrm{mg} \mathrm{kg}^{-1} \\
\text { (RZ) }\end{array}$ & $\begin{array}{l}\text { DON } \\
\mathrm{mg} \mathrm{kg}^{-1} \\
\text { (RFZ1) }\end{array}$ & $\begin{array}{l}\text { DON } \\
\mathrm{mg} \mathrm{kg}^{-1} \\
\text { (RFZ2) }\end{array}$ & $\begin{array}{l}\mathrm{IC} \\
\mathrm{mg} \mathrm{kg}^{-1} \\
(\mathrm{RZ})\end{array}$ & $\begin{array}{l}\mathrm{IC} \\
\mathrm{mg} \mathrm{kg}^{-1} \\
(\mathrm{RFZ1})\end{array}$ & $\begin{array}{l}\mathrm{IC} \\
\mathrm{mg} \mathrm{kg}^{-1} \\
(\mathrm{RFZ2})\end{array}$ \\
\hline \multirow{4}{*}{ Unleached } & CK & $15.4 \mathrm{a}^{*}$ & $16.8 \mathrm{a}$ & $20.3 \mathrm{a}$ & $0.2 \mathrm{~d}$ & $0.3 \mathrm{c}$ & $0.4 \mathrm{c}$ & $92.8 \mathrm{~b}$ & $95.2 \mathrm{bc}$ & $95.3 \mathrm{a}$ \\
\hline & DAP & $1.7 \mathrm{~d}$ & $2.7 \mathrm{~d}$ & $2.3 \mathrm{e}$ & $6.3 \mathrm{c}$ & $9.8 \mathrm{~b}$ & $8.6 \mathrm{~b}$ & $67.3 \mathrm{~d}$ & $73.7 \mathrm{f}$ & $67.7 \mathrm{c}$ \\
\hline & $\mathrm{DAP}+\mathrm{AC}$ & $9.8 \mathrm{bc}$ & $14.2 \mathrm{ab}$ & $8.0 \mathrm{c}$ & $21.3 \mathrm{a}$ & $26.1 \mathrm{a}$ & $23.4 \mathrm{a}$ & $75.2 \mathrm{~cd}$ & $88.4 \mathrm{~cd}$ & $82.9 \mathrm{~b}$ \\
\hline & $\mathrm{DAP}+\mathrm{PC}$ & $1.0 \mathrm{~d}$ & $1.7 \mathrm{~d}$ & $3.0 \mathrm{e}$ & $11.6 \mathrm{~b}$ & $11.8 \mathrm{~b}$ & $10.3 \mathrm{~b}$ & $82.5 \mathrm{c}$ & $82.2 \mathrm{de}$ & $79.1 \mathrm{~b}$ \\
\hline \multirow{4}{*}{ Leached } & CK & $11.8 \mathrm{~b}$ & $10.4 \mathrm{bc}$ & $10.8 \mathrm{~b}$ & $0.2 \mathrm{~d}$ & $0.3 \mathrm{c}$ & $0.4 \mathrm{c}$ & $78.4 \mathrm{c}$ & $79.2 \mathrm{ef}$ & $76.6 \mathrm{bc}$ \\
\hline & DAP & $1.2 \mathrm{~d}$ & $1.7 \mathrm{~d}$ & $1.7 \mathrm{e}$ & $0.1 \mathrm{~d}$ & $0.1 \mathrm{c}$ & $0.1 \mathrm{c}$ & $111.6 \mathrm{a}$ & $106.3 \mathrm{a}$ & $100.3 a$ \\
\hline & $\mathrm{DAP}+\mathrm{AC}$ & $2.4 \mathrm{~d}$ & $2.3 \mathrm{~d}$ & $2.0 \mathrm{e}$ & $0.1 \mathrm{~d}$ & $0.1 \mathrm{c}$ & $0.1 \mathrm{c}$ & $68.5 \mathrm{~d}$ & $63.8 \mathrm{~g}$ & $66.3 \mathrm{c}$ \\
\hline & $\mathrm{DAP}+\mathrm{PC}$ & $7.4 \mathrm{c}$ & $6.4 \mathrm{~cd}$ & $5.3 \mathrm{~d}$ & $0.1 \mathrm{~d}$ & $0.1 \mathrm{c}$ & $0.1 \mathrm{c}$ & $104.2 \mathrm{a}$ & $98.2 \mathrm{ab}$ & $102.8 \mathrm{a}$ \\
\hline
\end{tabular}

\footnotetext{
* Means followed by different letters within a column indicate significant differences between the treatments at $P<0.05 . \mathrm{CK}=\mathrm{Control} ; \mathrm{DAP}=\mathrm{Di}$-ammonium phosphate; $\mathrm{DAP}+\mathrm{AC}=\mathrm{Di}$-ammonium phosphate + acidic aged biochar; DAP + PC $=$ Di-ammonium phosphate + pine biochar; WHC $=$ Water holding capacity; DOC $=$ Dissolved organic $\mathrm{C}$; DON $=$ Dissolved organic $\mathrm{N}$; IC = Inorganic $\mathrm{C} ; \mathrm{RZ}=$ Rhizosphere; RFZ1 = Root-free zone 1; RFZ2 = Root-free zone 2.
} 
Table 6: Total $\mathrm{N}$ and $\mathrm{C}$ concentrations at rhizosphere and root-free zones

\begin{tabular}{|c|c|c|c|c|c|c|c|}
\hline \multicolumn{2}{|c|}{ Treatment } & $\begin{array}{c}\text { Total N } \\
\mathrm{mg} \mathrm{kg}^{-1} \\
\text { (RZ) }\end{array}$ & $\begin{array}{c}\text { Total N } \\
\mathrm{mg} \mathrm{kg}^{-1} \\
(\mathrm{RFZ1})\end{array}$ & $\begin{array}{c}\text { Total N } \\
\mathrm{mg} \mathrm{kg}^{-1} \\
(\mathrm{RFZ2})\end{array}$ & $\begin{array}{c}\text { Total C } \\
\mathrm{g} \mathrm{kg}^{-1} \\
\text { (RZ) }\end{array}$ & $\begin{array}{c}\text { Total C } \\
\mathrm{g} \mathrm{kg}^{-1} \\
(\mathrm{RFZ1})\end{array}$ & $\begin{array}{c}\text { Total C } \\
\mathrm{g} \mathrm{kg}^{-1} \\
(\mathrm{RFZ2})\end{array}$ \\
\hline \multirow{4}{*}{ Unleached } & CK & $6.2 \mathrm{c}^{*}$ & $6.1 \mathrm{~d}$ & $6.2 \mathrm{~d}$ & $1.5 \mathrm{~d}$ & $1.5 \mathrm{e}$ & $1.5 \mathrm{c}$ \\
\hline & DAP & $32.5 \mathrm{~b}$ & $33.0 \mathrm{c}$ & $31.6 \mathrm{c}$ & $1.4 \mathrm{~d}$ & $1.4 \mathrm{e}$ & $1.4 \mathrm{c}$ \\
\hline & $\mathrm{DAP}+\mathrm{AC}$ & $75.1 \mathrm{a}$ & $91.2 \mathrm{a}$ & $115.7 \mathrm{a}$ & $10.0 \mathrm{a}$ & $17.0 \mathrm{a}$ & $12.8 \mathrm{a}$ \\
\hline & $\mathrm{DAP}+\mathrm{PC}$ & $40.7 \mathrm{~b}$ & $45.4 \mathrm{~b}$ & $46.7 \mathrm{~b}$ & $6.6 \mathrm{c}$ & $6.4 \mathrm{~d}$ & $6.5 \mathrm{~b}$ \\
\hline \multirow{4}{*}{ Leached } & $\mathrm{CK}$ & $5.7 \mathrm{c}$ & $5.4 \mathrm{~d}$ & $6.2 \mathrm{~d}$ & $1.5 \mathrm{~d}$ & $1.4 \mathrm{e}$ & $1.5 \mathrm{c}$ \\
\hline & DAP & $9.1 \mathrm{c}$ & $9.6 \mathrm{~d}$ & $10.2 \mathrm{~d}$ & $1.4 \mathrm{~d}$ & $1.3 \mathrm{e}$ & $1.3 \mathrm{c}$ \\
\hline & $\mathrm{DAP}+\mathrm{AC}$ & $32.0 \mathrm{~b}$ & $35.7 \mathrm{c}$ & $47.3 \mathrm{~b}$ & $8.4 \mathrm{ab}$ & $10.9 \mathrm{~b}$ & $8.9 \mathrm{~b}$ \\
\hline & $\mathrm{DAP}+\mathrm{PC}$ & $9.4 \mathrm{c}$ & $10.2 \mathrm{~d}$ & $11.6 \mathrm{~d}$ & $6.9 \mathrm{bc}$ & $7.4 \mathrm{c}$ & $7.2 \mathrm{~b}$ \\
\hline
\end{tabular}

\footnotetext{
${ }^{*}$ Means followed by different letters within a column indicate significant differences between the treatments at $P<0.05 . \mathrm{CK}=$ Control; $\mathrm{DAP}=\mathrm{Di}$-ammonium phosphate; $\mathrm{DAP}+\mathrm{AC}=\mathrm{Di}$-ammonium phosphate + acidic aged biochar; DAP $+\mathrm{PC}=$ Di-ammonium phosphate + pine biochar; $\mathrm{WHC}=$ Water holding capacity; RZ = Rhizosphere; RFZ1 = Root-free zone 1; RFZ2 = Root-free zone 2 .
} 
Table 7: Plant biomass and N uptake

\begin{tabular}{|c|c|c|c|c|c|c|c|c|}
\hline \multicolumn{2}{|c|}{ Treatment } & $\begin{array}{c}\text { Shoot }^{*} \\
\text { biomass } \\
\left(\mathrm{mg} \mathrm{pot}^{-1}\right)\end{array}$ & $\begin{array}{c}\text { Root } \\
\text { biomass } \\
\left(\mathrm{mg} \mathrm{pot}^{-1}\right)\end{array}$ & $\begin{array}{l}\text { Shoot / Root } \\
\text { biomass } \\
\text { ratio }\end{array}$ & $\begin{array}{c}\text { Root } \\
\text { length } \\
\left(\mathrm{m} \mathrm{pot}^{-1}\right)\end{array}$ & $\begin{array}{c}\text { Plant } \\
\text { biomass / } \\
\text { Root length } \\
\left(\mathrm{mg} \mathrm{m}^{-1}\right)\end{array}$ & $\begin{array}{l}\text { Plant N } \\
\text { concent } \\
\text { ration } \\
\left(\mathrm{mg} \mathrm{g}^{-1}\right)\end{array}$ & $\begin{array}{c}\text { Plant N } \\
\text { uptake } \\
\left(\mathrm{mg} \mathrm{pot}^{-1}\right)\end{array}$ \\
\hline \multirow{4}{*}{ Unleached } & CK & $191 \mathrm{f}^{* *}$ & $71 \mathrm{~b}$ & $2.7 \mathrm{~d}$ & $22.8 \mathrm{~b}$ & $11.5 \mathrm{~cd}$ & $13.2 \mathrm{e}$ & $3.4 \mathrm{~d}$ \\
\hline & DAP & 233 def & $52 \mathrm{~b}$ & $4.5 \mathrm{bc}$ & $14.8 \mathrm{c}$ & $19.3 \mathrm{a}$ & $29.2 \mathrm{~b}$ & $8.2 \mathrm{c}$ \\
\hline & $\mathrm{DAP}+\mathrm{AC}$ & $402 \mathrm{bc}$ & $51 \mathrm{~b}$ & $7.9 \mathrm{a}$ & $22.8 \mathrm{~b}$ & $19.9 \mathrm{a}$ & $34.2 \mathrm{a}$ & $15.5 \mathrm{a}$ \\
\hline & $\mathrm{DAP}+\mathrm{PC}$ & $321 \mathrm{~cd}$ & $51 \mathrm{~b}$ & $6.3 \mathrm{ab}$ & $22.1 \mathrm{~b}$ & $16.8 \mathrm{ab}$ & $29.5 \mathrm{~b}$ & $10.8 \mathrm{~b}$ \\
\hline \multirow{4}{*}{ Leached } & CK & $211 \mathrm{ef}$ & $80 \mathrm{~b}$ & $2.6 \mathrm{~d}$ & $30.1 \mathrm{~b}$ & $9.7 \mathrm{~d}$ & $12.7 \mathrm{e}$ & $3.7 \mathrm{~d}$ \\
\hline & DAP & $283 \mathrm{de}$ & $67 \mathrm{~b}$ & $4.2 \mathrm{~cd}$ & $24.4 \mathrm{~b}$ & $14.3 \mathrm{abc}$ & $22.4 \mathrm{c}$ & $7.9 \mathrm{c}$ \\
\hline & $\mathrm{DAP}+\mathrm{AC}$ & $657 \mathrm{a}$ & 193 a & $3.4 \mathrm{~cd}$ & $51.2 \mathrm{a}$ & $16.6 \mathrm{ab}$ & $20.9 c$ & $17.8 \mathrm{a}$ \\
\hline & $\mathrm{DAP}+\mathrm{PC}$ & $513 \mathrm{ab}$ & $177 \mathrm{a}$ & $2.9 \mathrm{~d}$ & $52.6 \mathrm{a}$ & $13.1 \mathrm{bc}$ & $17.5 \mathrm{~d}$ & $12.0 \mathrm{~b}$ \\
\hline
\end{tabular}

\footnotetext{
${ }^{*}$ The data reported according to plant dry weight.

** Means followed by different letters within a column indicate significant differences between the treatments at $P<0.05 . \mathrm{CK}=\mathrm{Control} ; \mathrm{DAP}=\mathrm{Di}$-ammonium phosphate; $\mathrm{DAP}+\mathrm{AC}=\mathrm{Di}$-ammonium phosphate + acidic aged biochar; DAP + PC $=$ Di-ammonium phosphate + pine biochar; WHC $=$ Water holding capacity.
} 